\author{
Joanna Bogołębska \\ Uniwerystet Łódzki \\ e-mail: joannabogolebska@wp.pl
}

\title{
UWARUNKOWANIA FUNKCJONOWANIA AKTYWÓW BEZPIECZNYCH (SAFE ASSETS) WOBEC PRZEMIAN W MIĘDZYNARODOWYM SYSTEMIE WALUTOWYM
}

CONDITIONS FOR THE OPERATION

\section{OF SAFE ASSET MARKET AND THE CHANGES IN THE INTERNATIONAL MONETARY SYSTEM}

DOI: 10.15611/pn.2018.523.05

JEL Classification: F30, F32

Streszczenie: Tradycyjnie kluczowym źródłem dostarczania aktywów bezpiecznych na globalnych rynkach finansowych była emisja długu publicznego przez kraje rozwinięte. Istotną rolę w popycie na ten dług odgrywał sektor oficjalny krajów rozwijających się w ramach polityki akumulacji rezerw walutowych. Spadek długu rządowego postrzeganego jako bezpieczny, wraz ze spadkiem innych źródeł kreacji długu bezpiecznego w okresie pokryzysowym, przy wciąż silnym popycie na niego powoduje istotne wyzwania dla stabilności międzynarodowego systemu walutowego (MSW). Problem w nierównowadze podaży i popytu na safe assets jest o tyle trudny do rozwiązania, że w dużej mierze wiąże się z przekształceniami roli krajów emerging markets i rozwiniętych w gospodarce globalnej. Celem artykułu jest syntetyczne naświetlenie tego złożonego związku i próba identyfikacji możliwych rozwiązań. Zastosowaną metodą badawczą jest przegląd literatury światowej w tym zakresie.

Słowa kluczowe: safe asset, międzynarodowy system walutowy, paradoks Triffina.

Summary: Traditionally, the issuance of sovereign debt by the advanced economies has been a key source of safe assets in global financial markets. The crucial role in demand for them is played by the official sector of emerging market economies performing reserve accumulation policy. The decline of sovereign debt perceived as safe, as well as of other sources of debt in the post-crisis period, combined with the sharp increase in demand for them, has raised concerns about the stability of the international monetary system. The imbalance of supply and demand for safe assets is connected with the changing role of emerging market and advanced countries in the global economy. The aim of the article is to present the interlinkages between these factors and to identify the possible solutions. The author concentrates on the review of the literature.

Keywords: safe asset, international monetary system, Triffin dilemma. 


\section{Wstęp}

W ostatnich latach coraz szerzej zaczęto wyrażać opinie, że gospodarce globalnej brakuje aktywów bezpiecznych, co w połączeniu z rosnącym popytem może niekorzystnie wpłynąć na globalny system finansowy. Obawy, że gospodarkę globalną czeka niedobór bezpiecznych aktywów (shortage of safe assets), narażający system finansowy na niestabilność, wyrażał m.in. MFW w 2012 r. Argumenty zwolenników tezy o niedoborze safe assets pomijają jednak zdolność uczestników rynku do dostosowania do zmieniających się uwarunkowań. Wśród przyczyn globalnego niedopasowania popytu i podaży safe assets zwraca się uwagę na szybki wzrost gospodarczy krajów zaliczanych do grupy emerging markets w połączeniu ze słabym rozwojem ich rynków finansowych. W konsekwencji tego powstał nacisk na obniżkę światowych stóp procentowych, co przyczyniało się także do tzw. nierównowag globalnych. Jako drugą przyczynę globalnego niedoboru aktywów zaliczanych do bezpiecznych wskazuje się globalny kryzys finansowy i wynikające z niego konsekwencje dla rynków finansowych. Czy oraz w jaki sposób gospodarka światowa poradzi sobie z problemem niedopasowania podaży aktywów bezpiecznych do popytu jest warunkowane obecnym, a także będzie determinowało przyszły kształt międzynarodowego systemu walutowego (MSW).

\section{Pojęcie aktywów bezpiecznych}

Powszechnie safe asset jest definiowany jako każdy dług, który gwarantuje ustaloną wartość pieniądza w przyszłości bez ryzyka niewypłacalności emitenta. Stanowi on wiarygodny środek przechowywania wartości oraz jest kluczowym źródłem płynności.

P. Gourinchas i in. definiują je jako płynne roszczenie wobec długu pozbawionego ryzyka niewypłacalności. Jednocześnie wyodrębniają 3 źródła kreacji safe assets:

- pasywa banku centralnego (gotówka),

- dług rządowy,

- rynek prywatnych safe assets [Gourinchas, Jeanne 2012].

Dwa pierwsze źródła nazywają tradycyjnymi, zwracając uwagę, że wyłonienie się trzeciego związane było z procesami sekurytyzacji, a także funkcjonującą międzynarodową asymetrią w popycie i podaży aktywów finansowych. Wskazują jednocześnie, że aktywa z emisji prywatnych nie mogą stanowić wystarczającej ochrony przed szokami globalnymi. Mogą ją jedynie stanowić aktywa z emisji publicznych, jeśli są dodatkowo wsparte polityką pieniężną.

Ponadto główną cechą safe assets jest ich niewrażliwość na informację. Oznacza to, że nie ma asymetrii w informacji odnośnie do aktywu, więc na jego rynek nie będzie miała wpływu niepłynność pochodząca z problemu negatywnej selek- 
cji. Wiarygodność aktywu jest pewna, co redukuje potrzebę zbierania informacji z punktu widzenia inwestora.

P. Gourinchas i in. podkreślają także, że safe asset jest definiowany jako każdy dług, który gwarantuje stałą ilość pieniądza w przyszłości bez ryzyka niewypłacalności. Dla posiadaczy aktywu bezpieczeństwo zależy także od ich potrzeb płynnościowych, np. zgłaszający popyt na długoterminowy safe asset będzie uwzględniał ryzyko inflacji. Uwarunkowania indywidualne w popycie na safe asset powodują, że za aktyw ten uznamy gotówkę (w tym gwarantowane depozyty) oraz każdy dług, który podlega handlowaniu, jest płynny (co jest uwarunkowane głębokością rynku na którym podlega obrotowi) oraz ma najwyższy credit rating. Co istotne zatem, o tym, czy aktyw jest uznany za bezpieczny, decyduje nie tylko charakterystyka emitenta, lecz także cechy rynku, na którym podlega obrotowi. Szczególnie istotne jest zachowanie banku centralnego (lub innej instytucji zaufania) - jego zobowiązanie do kupna aktywu, jeśli jego cena spada poniżej pewnego poziomu, może spowodować, że każdy aktyw może nabrać cechy aktywu bezpiecznego.

\section{Aktywa bezpieczne - uwarunkowania popytowe}

Inwestorzy zgłaszają popyt na aktywa bezpieczne, aby mieć wiarygodny środek tezauryzacji, stabilne zabezpieczenie w transakcjach na rynku derywatów i innych transakcjach prywatnych i banku centralnego (transakcje repo), wypełnić wymogi ostrożnościowe. Służą one także jako benchmark do wyceny innych, bardziej ryzykownych aktywów. Są substytutem zaufania na rynkach finansowych. Wreszcie stanowią kluczowy komponent operacji polityki pieniężnej. Poszczególne grupy inwestorów kładą nacisk na odmienne funkcje safe assets, co powoduje różne efekty cenowe na poszczególnych rynkach i utrudnia wskazanie jednolitej „ceny bezpieczeństwa" (price of safety).

Badania empiryczne wskazują, że w USA roczny udział procentowy aktywów bezpiecznych w stosunku do wszystkich emitowanych aktywów pozostawał na względnie stałym poziomie około $33 \%$ przez ostatnie 30 lat, do czasu globalnego kryzysu finansowego z 2007 r. Jednocześnie wszystkie aktywa stanowiły czterokrotność PKB w 1952 r., zaś w 2010 dziesięciokrotność PKB, co obrazuje wzrost popytu na dolarowe aktywa bezpieczne [Gorton i in. 2012]. Nie odzwierciedla to jeszcze oczywiście wzrostu globalnego popytu na dolarowe safe assets. Dla przykładu - o ile w 2000 r. podmioty zagraniczne posiadały 35,2\% obligacji skarbowych USA, o tyle w 2009 r. już 54,1\%. A zatem, w posiadaniu zagranicznych inwestorów w 2009 r. była ponad połowa amerykańskich obligacji skarbowych oraz prawie 1/5 korporacyjnych papierów dłużnych [Warnock 2010]. Z kolei P. Gourinchas $\mathrm{i}$ in. zwracają uwagę, że w najważniejszych gospodarkach (USA, Wielka Brytania, Niemcy, Francja) popyt na safe assets ze strony prywatnego sektora realnego był na stabilnym poziomie. Jego udział w krajowym produkcie wynosi około $80 \%$ PKB [Gourinchas, Jeanne 2012]. 
Jednocześnie na skutek procesów sekurytyzacyjnych w USA wzrosła podaż ryzykownych aktywów. Różnicę między popytem i podażą safe assets wypełniły pozostałe gospodarki świata w postaci zagranicznego sektora oficjalnego i finansowego. Większość wzrostu popytu (jak również podaży) na safe assets pochodziła z systemu finansowego, a nie realnego. Wyjątkiem jest Japonia, gdzie gospodarstwa domowe zgłaszają wysoki popyt na aktywa bezpieczne, co tłumaczy się czynnikiem demograficznym. Rosnący popyt na safe assets po 2007 r. wynika także $\mathrm{z}$ reform regulacyjnych $\mathrm{w}$ systemie finansowym oraz wzrostu ich wykorzystania w operacjach banków centralnych.

Rosnący popyt z zagranicy stanowił istotną stymulantę dla amerykańskich i europejskich rynków finansowych. W latach 2002-2007 rynki prywatne dzięki sekurytyzacji bardziej ryzykownych aktywów dostarczyły ogromnej ilości safe assets z emisji prywatnych. Nowe regulacje ostrożnościowe wprowadzane w okresie pokryzysowym mogą utrudnić przedkryzysową łatwość, z jaką sektor prywatny tworzył aktywa bezpieczne.

Popyt sektora finansowego w USA na rządowe aktywa bezpieczne był stały od lat 70. do globalnego kryzysu finansowego, kiedy to wewnętrzna płynność (rozumiana jako płynność tworzona na skutek pożyczania środków przez podmioty tego samego sektora) została zastąpiona płynnością zewnętrzną (roszczenia wobec podmiotów spoza sektora, należy do niej dług rządowy). Wynika to z tego, że zasadniczym problemem aktywów bezpiecznych emitowanych przez sektor prywatny jest zdolność do pogarszania się ich jakości w sytuacji negatywnego szoku, a więc kiedy są najbardziej potrzebne. Zdolność rządu do opodatkowania czyni jego dług bezpieczniejszym w stosunku do długu sektora prywatnego.

Wobec rosnącego popytu na dług rządowy jako safe asset powstaje jednak ryzyko niestabilności finansowej wynikającej z zachowań stadnych (herding behavior) $\mathrm{i}$, runu” na dług publiczny [IMF 2012].

Popyt na safe assets odzwierciedla różne napięcia i nieefektywności występujące na rynkach finansowych. W przypadku zagranicznego sektora oficjalnego przejawia się to w akumulacji rezerw (motyw ostrożnościowy oraz merkantylistyczny).

W analizie banków centralnych jako podmiotów zgłaszających popyt na aktywa bezpieczne zwraca się uwagę na kolejność celów w konstrukcji portfela: bezpieczeństwo, płynność, stopę zwrotu. Z punktu widzenia banku centralnego, płynność oraz niskie ryzyko kredytowe i rynkowe są kluczowymi czynnikami określającymi zakres bezpieczeństwa aktywu, który musi być gotowy do szybkiej sprzedaży i niepodatny na straty wartości. W $2011 \mathrm{r}$. 64\% portfela rezerw stanowiły dłużne papiery wartościowe, z czego większość była papierami skarbowymi [MFW 2012].

Wobec intensywnej polityki akumulacji rezerw ze strony krajów emerging markets i ich niezdolności do kreowania aktywów bezpiecznych powstaje pytanie, czy priorytetem z punktu widzenia stabilności MSW powinno być zwiększanie podaży safe assets, czy też zarządzanie powstałymi nieefektywnościami? 


\section{Aktywa bezpieczne - uwarunkowania podażowe}

P. Gourinchas i in. zwracają uwagę, że spadek podaży aktywów bezpiecznych prowadzi do wzrostu ich ceny, co oznacza niższe realne stopy procentowe. Do pewnego stopnia może to mieć efekt stabilizujący, gdyż zwiększając efektywną podaż, czyni pożyczkobiorcę bardziej wypłacalnym. Ale w zbyt dużej skali spadek realnych stóp procentowych może mieć efekt destabilizujący ze względu na:

- pojawienie się ,pułapki płynności”. Na skutek spadku podaży safe assets gospodarka może wpaść w pułapkę płynnościową trwającą tak długo, jak długo utrzymuje się ten spadek;

- pojawienie się niestabilności finansowej. Wyrazem jej może być „,prawo Greshama" dla baniek na rynku aktywów (bardziej ryzykowna bańka wypiera bezpieczniejszą). Spadek podaży safe assets czyni gospodarkę podatną na pojawienie się ryzyka baniek na rynku aktywów [Gourinchas, Jeanne 2012].

Zatem wydaje się, że istotne jest, aby utrzymać wystarczającą podaż safe assets w stosunku do rozmiaru gospodarki.

Zdaniem J. Landaua w podaży safe assets występują dwie prawidłowości:

- safe assets mają w miarę stały udział w całkowitych aktywach finansowych gospodarki;

- finansowe i rządowe pasywa są substytutami: fluktuacje w zasobach długu publicznego wypychają lub wpychają pieniądz i dług emitowany przez pośredników finansowych. W długim okresie system finansowy dostosowuje się tak, że zasada „stałego udziału” jest respektowana [Landau 2013].

Podobnego zdania są P. Gourinchas i in. - niedobór safe assets nie jest problemem. W gospodarce działają endogeniczne, samokorygujące mechanizmy, które powodują, że system gospodarczy potrafi się z takim niedoborem uporać. Bardziej zasadna wydaje się obawa o kompozycję safe assets i o to, jak system finansowy uczynić stabilnym. Zwracają oni uwagę, że definicja safe assets, rozumiana jako rozgraniczenie między aktywem postrzeganym jako bezpieczny i pozostałymi, zmieniała się w czasie. Aktywa, które były postrzegane jako bezpieczne (jak aktywa sektora prywatnego w USA czy zadłużenie rządowe w krajach peryferyjnych strefy euro), okazywały się niebezpieczne.

W odpowiedzi na zwiększony popyt zagranicy na bezpieczne aktywa USA powiększyły podaż aktywów, co jednocześnie stało się bodźcem do tworzenia toksycznych aktywów [Caballero 2009]. Zatem przed globalnym kryzysem finansowym emitenci prywatni i publiczni uzupełniali się w kreacji aktywów bezpiecznych.

Jeśli chodzi o sektor dostarczający aktywów bezpiecznych, to z badań P. Gourinchasa $\mathrm{i}$ in. wynika, że największy komponent aktywów bezpiecznych stanowią te emitowane przez sektor finansowy. Roszczenia wobec sektora prywatnego mają jednakże wkomponowany element ryzyka, co jest konieczne, aby chronić system finansowy przed pokusą nadużycia (moral hazard). Globalny kryzys finansowy podważył traktowanie jako bezpiecznych aktywów dostarczanych przez sektor prywatny. 
Dlatego najlepszymi kandydatami do roli aktywów bezpiecznych powinny pozostać tradycyjne dwa: gotówka oraz dług rządowy. Jak wskazują P. Gourinchas $\mathrm{i}$ in., z czterech najważniejszych gospodarek (USA, kraje strefy euro, Chiny, Japonia) obecnie tylko dwie - USA i Japonii - dostarczają w skali globalnej publicznych aktywów bezpiecznych. Można tu jeszcze uwzględnić Szwajcarię, Niemcy i do pewnego stopnia Wielką Brytanię [Gourinchas, Jeanne 2012]. Nie wszyscy się jednak zgadzają z tezą, że dług rządowy jako safe asset spadł w okresie pokryzysowym. Dla przykładu OECD, używając szerszej definicji safe assets, wskazuje, że te bezpieczne aktywa rządowe wzrosły od 2007 r. [Bloomenstein 2013].

\section{Przemiany w międzynarodowym systemie walutowym a problem aktywów bezpiecznych}

Podstawowa przemiana w MSW, jaka nastąpiła w ostatnich dekadach, mająca wpływ na popytowo-podażowe uwarunkowania safe assets to „odwrócenie roli”" dwóch grup krajów (krajów emerging markets versus kraje rozwinięte) w gospodarce światowej. Polega to na paradoksalnie odmiennym w stosunku do poziomu rozwoju gospodarczego kształtowaniu się pozycji zewnętrznych tych krajów. W ten sposób kraje rozwinięte, jak: USA, Australia, Nowa Zelandia, Kanada, zaliczane są do dłużników netto, zamiast kredytodawców netto. Z kolei do krajów mających status dłużników netto, zamiast kredytodawców netto, zalicza się kraje emerging markets na czele z Chinami, ale także Tajwan, Hongkong, Malezję czy Wenezuelę. Dodatkowo w analizie obu grup krajów zwraca uwagę kontrast pomiędzy ich udziałami w światowym wzroście PKB oraz długu. Kraje emerging markets mają dużo większy udział we wzroście światowego PKB niż globalnego długu publicznego. W $2007 \mathrm{r}$. odpowiadały za 25\% światowego PKB i 17\% światowego długu, do końca 2016 r. mają odpowiadać za 38\% światowego PKB oraz 14\% światowego długu. Z kolei cztery główne obszary kreujące waluty rezerwowe (USA, Japonia, strefa euro, Wielka Brytania) w 2011 r. odpowiadały łącznie za 58\% globalnego PKB oraz 81\% globalnego długu. Same USA odpowiadają za 37\% wzrostu globalnego długu w latach 2007-2011 oraz 40\% wzrostu długu w latach 2011-2016. Z kolei ich udział we wzroście globalnego PKB wynosi odpowiednio dla tych okresów 8\% oraz 18\% [Prasad 2011]. Zatem kraje emerging markets, głównie Azji Południowo-Wschodniej, odgrywają główną rolę w globalnym transferze oszczędności. Od połowy lat 90. ich aktywa netto denominowane w walucie zagranicznej rosną. W aktywach zagranicznych tych krajów wyraźną rolę odgrywają rezerwy walutowe. W $2010 \mathrm{r}$. stanowiły one odpowiednio 47\% aktywów zagranicznych w przypadku Brazylii, 69\% Chin, 68\% Indii, 37\% Rosji. Średni udział aktywów rezerwowych w całkowitych aktywach zagranicznych krajów emerging markets wzrósł z 32\% w 2000 r. do

1 Terminu tego użył E. Prasad w celu zobrazowania zmian pozycji krajów emerging markets i rozwiniętych w gospodarce światowej. 
53\% w 2010 r. Utrzymywane są one głównie w obligacjach skarbowych czterech głównych bloków gospodarczych: USA, strefy euro, Japonii i Wielkiej Brytanii. W latach 2003-2010 rezerwy walutowe krajów emerging markets w przeliczeniu na dol. wzrosły z 1,3 do 6,5 bln dol., z czego $2 / 3$ były zainwestowane w USD. O ile jednak zagraniczny sektor publiczny krajów emerging markets jest istotnym posiadaczem amerykańskich pasywów, o tyle sektor publiczny USA ma niewielkie ilości aktywów zagranicznych. Należy także zauważyć, że $90 \%$ pasywów zagranicznych USA jest denominowanych w dolarach. Możliwość zaciągania długu we własnej walucie jest wyrazem nadzwyczajnego przywileju (exorbitant privilege) kraju emitującego walutę rezerwową. W przypadku USA istotne jest także, że rośnie udział zagranicznego sektora publicznego w posiadaniu amerykańskich obligacji skarbowych (z 6\% w latach 70. do 40\% w latach 90.). Zatem, obok zasadniczej zmiany pozycji krajów w MSW, istotne znaczenie ma odmienna struktura i waluta denominowania ich pozycji zewnętrznych.

\section{Popyt na aktywa bezpieczne a uwarunkowania podaży - współczesny paradoks Triffina}

Wzrost otwartości finansowej oraz ekspozycji na zmienne przepływy kapitałowe wraz ze słabym rozwojem rynku finansowego krajów emerging markets spowodował wzrost popytu sektora oficjalnego tych krajów na bezpieczne aktywa. Zwiększony popyt na rezerwy walutowe rozmiękcza ograniczenia budżetowe w polityce fiskalnej krajów emitujących walutę rezerwową. Tworzy pole dla nadmiernie ekspansywnej polityki fiskalnej. Ciągłe zwiększanie długu zagranicznego netto powoduje zjawisko „rozcieńczenia długu” (debt dilution), dewaluacji istniejącego długu. Nadmierny popyt na rezerwy dolarów obniża oprocentowanie skarbowych papierów wartościowych poniżej wartości odpowiadającej poziomowi, który utrzymywałby się, gdyby popyt na te papiery zgłaszał jedynie sektor prywatny. Wynika to $\mathrm{z}$ faktu, że akumulacja rezerw walutowych jest niewrażliwa na stopę zwrotu z aktywów. Pożyczkodawcy nie traktują zakupu waluty rezerwowej jako inwestycji. Traktują go raczej jako instrument ochronny w przypadku przyszłych kryzysów walutowych [Steiner 2012].

Niższe oprocentowanie zmniejsza koszty obsługi długu i stwarza pole do zwiększenia deficytu i długu publicznego [Wojtyna 2013]. Każda dodatkowa jednostka długu wzmaga prawdopodobieństwo niewypłacalności, co nakłada ograniczenie na cały dług zagraniczny. Pokusa zwiększania deficytu budżetowego i deficytu na rachunku obrotów bieżących obniża dyscyplinę dla krajowej polityki gospodarczej [Daniel 2001].

Nadmierny popyt na rezerwy może skutkować nie tylko stopniową utratą zaufania do stabilnej wartości waluty rezerwowej, lecz także zaniżoną wyceną ryzyka przez pośredników finansowych (a w konsekwencji bąblami na rynkach aktywów). 
Ponieważ oprocentowanie papierów skarbowych (jako aktywów wolnych od ryzyka rynkowego) stanowi punkt odniesienia dla wyceny innych aktywów finansowych, jego redukcja może skłaniać pośredników finansowych do zaniżonej wyceny wszystkich rodzajów ryzyka, czego następstwem będzie nadmierna ekspansja kredytu i wadliwa alokacja kapitału w kraju emitującym walutę rezerwową [Wojtyna 2013].

Z punktu widzenia krajów akumulujących rezerwy powstaje wątpliwość, czy są one nadal aktywami bezpiecznymi w warunkach wzrastającego długu publicznego krajów rozwiniętych. Dylemat ten tworzy swoistą współczesną odmianę paradoksu Triffina (tzw. paradoks Triffina II), w którym centralny element niespójności systemowej jest sprowadzony do wymiaru fiskalnego. Dylemat Triffina powstaje, gdy wzrastający popyt na aktywa rezerwowe ogranicza zdolność emitenta do dostarczenia takiej ilości, która pozwoliłaby zachować wiarygodność i gwarancję stabilnej wartości aktywów. We współczesnej odmianie paradoksu Triffina nie ma już wątpliwości, czy USA będą miały odpowiednią ilość złota, aby spłacić wszystkie swoje zobowiązania (jak w paradoksie Triffina I), ale czy będą miały na tyle duży potencjał fiskalny, aby bieżąco regulować płatności z tytułu rosnącego zadłużenia. Zdaniem M. Obstfelda problem paradoksu Triffina II nie tylko tkwi w wiarygodności, ale zasadniczo w potencjalnej niewypłacalności fiskalnej kraju emitenta. Gospodarka światowa potrzebuje stałej ekspansji zasobów długu publicznego jako miernika wartości, ale ekspansja ta zagraża zdolności długu do pozostawania aktywem bezpiecznym [Obstfeld 2011].

Elementami nadającymi dynamikę współczesnemu paradoksowi są dwie asymetrie:

- wspomniany już rozwój krajów emerging markets szybszy niż krajów rozwiniętych;

- to kraje rozwinięte pozostają bardziej wiarygodne niż kraje emerging markets.

Łącznie prowadzą one do tego, że popyt na dług krajów rozwiniętych przewyższa bezpieczny poziom podaży długu publicznego, powodując utratę jego wiarygodności jako safe asset.

\section{Implikacje uwarunkowań popytowo-podażowych aktywów bezpiecznych dla międzynarodowego systemu walutowego}

Wzrastającemu w okresie pokryzysowym popytowi na aktywa bezpieczne, pochodzącemu zwłaszcza z sektora finansowego, towarzyszyła kurcząca się podaż ze strony rządów i sektora prywatnego. Analiza teoretyczna i empiryczna literatury wskazuje, że nie jest oczywiste, czy należy się obawiać rosnącego rozdźwięku między popytem i podażą safe assets.

Analiza doświadczeń kryzysowych wskazuje, że dolar wzmocnił swoją pozycję jako waluta denominowania aktywów bezpiecznych. Powstaje jednak wątpliwość, 
czy w długim okresie wielowalutowy system kreowania safe assets może być systemem stabilnym.

Pokryzysowy wzrost popytu na aktywa bezpieczne ze strony sektora prywatnego (co ma związek z wdrażanymi regulacjami ostrożnościowymi) może oznaczać, że kraje akumulujące rezerwy będą zmuszone konkurować z sektorem prywatnym o dostęp do długu rządowego krajów emitujących walutę rezerwową. $Z$ drugiej strony, oczekiwanie deprecjacji walut krajów rozwiniętych lub obniżenia realnej wartości długu przez inflację rodzi ryzyko straty kapitałowej ze zakumulowanych rezerw dla posiadaczy. Tworzy to ryzyko gwałtownych zmian w strukturze rezerw walutowych i może zachęcać do gwałtownej, nieskoordynowanej dywersyfikacji portfela, co może prowadzić do wzrostu zmienności kursów walutowych.

\section{Uwagi końcowe}

Naturalną metodą na wyeliminowanie niestabilności finansowej wynikającej z niedoboru safe assets wydaje się dostarczanie publicznych aktywów bezpiecznych.

Jednakże działanie takie może wymagać koordynacji z polityką pieniężną. Odpowiednia polityka pieniężna może poprawić bezpieczeństwo safe assets - bez konsekwencji lub z minimalnymi konsekwencjami dla stabilności cenowej. Bank centralny, pełniąc funkcję pożyczkodawcy ostatniej instancji wobec rządu, może pomóc utrzymać status safe asset dla długu rządowego i oddalić ryzyko niewypłacalności. Jednak należy pamiętać o występowaniu tu swoistej wymienności między utrzymaniem statusu safe asset a ryzykiem monetyzacji długu.

Jak wynika ze współczesnej odmiany paradoksu Triffina, globalna rzadkość aktywów bezpiecznych będzie się zwiększać, jako że globalny popyt, łączący się ze wzrostem gospodarczym, przewyższa podaż - związaną ze wzrostem gospodarczym i stabilnością fiskalną w USA. Konsolidacja fiskalna krajów rozwiniętych może dodatkowo utrudnić zaspokajanie popytu na safe asset, szczególnie ze strony zagranicznego sektora oficjalnego.

Wśród rozwiązań problemu „potencjalnej rzadkości aktywów rezerwowych” M. Obstfeld dostrzega kilka możliwych rozwiązań:

- przeorientowanie popytu na rezerwy w kierunku bardziej ryzykownych aktywów, m.in. przez kierowanie kapitału do tzw. Państwowych Funduszy Majątkowych (SWF);

- wzrost wiarygodności krajów emerging markets, co prowadziłoby do obniżenia ich popytu na rezerwy, a docelowo uczyniło z nich dostawców aktywów rezerwowych;

- przyspieszenie wzrostu w krajach rozwiniętych wraz ze spowolnieniem w krajach emerging markets.

M. Obstfeld zwraca uwagę, że ostatnie dwa rozwiązania należą do długookresowych, ale nieuniknionych. W przeciwnym razie paradoks Triffina doprowadzi do niestabilności MSW. Wskazuje, że świadczą o tym niedawne doświadczenia go- 
spodarki światowej - wzrost popytu na złoto w reakcji na napięcia w zadłużeniu publicznym krajów rozwiniętych [Obstfeld 2011].

J. Landau wskazuje z kolei, że w sytuacji wzrastającego popytu netto na safe assets (ze strony sektora zarówno oficjalnego, jak i prywatnego) oraz wobec spodziewanej konsolidacji fiskalnej w krajach emitujących walutę rezerwową problem potencjalnej nierównowagi ex ante w podaży i popycie na safe assets może być rozwiązany przez:

- przesunięcie definicji safe asset - aktywa niższej jakości mogą zastąpić aktywa wyższej jakości. Landau zwraca uwagę, że dostosowania takie miały miejsce w czasie ostatniego kryzysu finansowego. Był to efektywny, choć niewątpliwie kontrowersyjny antycykliczny instrument dostarczania płynności;

- dostosowania cenowe - kiedy realna stopa wolna od ryzyka dostosowuje się, aby zapewnić równowagę między podażą i popytem na safe assets;

- delewarowanie w systemie finansowym i redukcję wolumenu prywatnej płynności [Landau 2013].

W swoim raporcie MFW również zwraca uwagę, że rozwiązaniem potencjalnego rozdźwięku między popytem a podażą safe assets jest wspieranie działań zwiększających zdolność krajów emerging markets do emitowania własnych aktywów bezpiecznych [MFW 2012].

Zdaniem E. Fahri i in. nieuniknione wydaje się przejście do sytemu, gdzie globalne dostarczanie safe assets jest zdecentralizowane. W takim systemie wielopolarowym globalna podaż safe assets kształtowałaby się w korelacji ze wzrostem globalnej gospodarki, zapewniając odpowiedni globalny poziom safe assets, a dochód $\mathrm{z}$ emisji aktywów byłby równomiernie dystrybuowany między emitentów. Rozwiązanie takie najprawdopodobniej prowadziłoby do spadku roli dolara. Redukcja internacjonalizacji dolara mogłaby się wiązać ze wzrostem internacjonalizacji walut krajów emerging markets, np. chińskiego renminbi (RMB). Spadek zakresu internacjonalizacji dolara miałby oczywiście pewne konsekwencje dla USA, w tym dla polityki fiskalnej. Redukcja popytu na dług sektora oficjalnego USA mogłaby doprowadzić do wzrostu kosztów jego finansowania, w konsekwencji do wyższego ciężaru zadłużenia fiskalnego i wypychania krajowych wydatków sektora publicznego i prywatnego. Zredukowany popyt na amerykańskie aktywa skarbowe może prowadzić do deprecjacji dolara [Goldberg 2011].

Zdaniem P. Gourinchas i in. rozwiązanie problemu w postaci zwiększenia podaży safe assets $\mathrm{w}$ ramach systemu wielopolarowego nie jest oczywiste, gdyż w systemie takim arbitraż między safe assets może raczej wygenerować aniżeli ograniczyć zmienność na rynkach finansowych. Może to oznaczać konieczność koordynowania w skali globalnej polityki pieniężnej i fiskalnej globalnych emitentów safe assets, najprawdopodobniej przy włączeniu do tego typu działań MFW. 


\section{Literatura}

Blommestein H., 2013, Redefining safe sovereign assets in OECD area may give less gloomy outlook, Bloomberg Brief, 1 March, www.suerf.org/download/vienna13/papers/1blommestein.pdf.

Caballero R., 2009, Global imbalances and financial fragility, American Economic Review, no. 99(2).

Caballero R., Ferhi E., Gourinchas P., 2015, Global imbalances and currency wars at the zero lower bound, NBER Working Paper, no. 21670.

Daniel B., 2001, A fiscal theory of currency crises, International Economic Review, vol. 42, no 4.

Fahri E., Gourinchas P., Rey H., 2011, Reforming the International Monetary system, London, UK, Centre for Economic Policy Research.

Goldberg L., 2011, The international role of the dollar: does it matter if this changes?, Federal Reserve Bank of New York Staff Reports, no. 522.

Gorton G., Lewellen S., Metrick A., 2012, The safe asset share, American Economic Review: Papers and Proceedings, 102(3), May.

Gourinchas P., Jeanne O., 2012, Global safe assets, BIS Working Paper no 399.

International Monetary Fund, 2012, Global Financial Stability Report: the Quest for Lasting Stability, April.

Landau J., 2013, Global Liquidity: Public and Private, Federal Reserve Bank of Kansas City, Economic Symposium.

Obstfeld M., 2011, The international monetary system: living with asymmetry, NBER Working Paper, no 17641 .

Prasad E., 2011, Role Reversal in Global Finance, Federal Reserve Bank of Kansas City, Economic Symposium.

Steiner A., 2012, Reserve Accumulation and Financial Crisis: from Individual Protection to Systemic Risk, University of Osnabrueck.

Warnock E., 2010, How dangerous is U.S. government debt? The risks of a sudden spike in U.S. interest rates, Capital Flows Quarterly, Council on Foreign Relations.

Wojtyna A., 2013, Zmiany instytucjonalne w reakcji na obecny kryzys, PWE, Warszawa. 